\title{
Gold in Book Binding
}

\author{
THE ORIGINS OF THE CRAFT
}

\section{Giulia Bologna}

Director, Historical Archives and Trivulziana Library, Milan, Italy

\begin{abstract}
From early days, extensive use has been made of gold for the decoration of the covers of manuscripts and books, especially those of a sacred nature. The development of this aspect of the craft of bookbinding, which reached its zenith in the 17th and 18th centuries, is described below.
\end{abstract}

In ancient times gold was used in the East for making all kinds of objects. Later, during the Middle Ages and the Renaissance period, when less extensive use was made of gold, the metal was reserved mainly for ornamental and decorative purposes. It was therefore natural that it should have begun to play an important part in the external adornment of books and their bindings. This continued into the 17th and 18th centurnes when gold fell in esteem for this application, and precious stones won greater favour.

\section{Early Bindings}

The history of book binding is closely connected with the form and shape of the book itself. The Greeks and Romans kept their scrolls in boxes and containers, but with the introduction of folio sheets of papyrus and parchment in the 1st century A.D. new methods were sought for the protection of the volumes so formed. In Egypt and the Near East the practice was adopted of using two wooden boards between which the folio sheets, folded into sections, were inserted. These were then sewn to the covers with stitches that differed in their type and detail according to the locality and the period.

The oldest bindings that have come down to us in the West date back to the 7th century. It was then that gold made its brilliant début on the splendid front cover of the 'Gospels of Theolinda' which are preserved at Monza, near Milan. The cover consists of a fine sheet of gold, bearing eight cameos set in the form of a cross.

In the early Middle Ages, binding methods employed in the western world were, in fact, quite different from any previous ones. It became customary to stitch the page sections onto two raised bands made of leather strips running the length of the spine. The rather fragile ends of these bands were strengthened with braid or plaited silk. After sewing the boards to the page sections by means of the two bands, the covers were adorned in various ways.

Rare codices, sacred texts in particular, were adorned with gold, precious stones, enamels and ivory. Manuscripts were normally embellished with fabric and decorated leatherwork. Metal studs and angle pieces, often gilded, were used to protect the covers, as such books were placed horizontally on their shelves. For the same reason, titles were inscribed lengthwise on the spine or on a label which was attached to one of the two cover boards. In Europe, plaques for the enrichment of the covers were made of gold, engraved silver or ivory, all set with precious stones to create an effect of magnificence, especially in the Carolingian epoch. At this time the Near East began to produce bindings adorned with polychrome enamels and a profusion of gold; religious scenes and the figures of saints were depicted in the manner characteristic of contemporary taste.

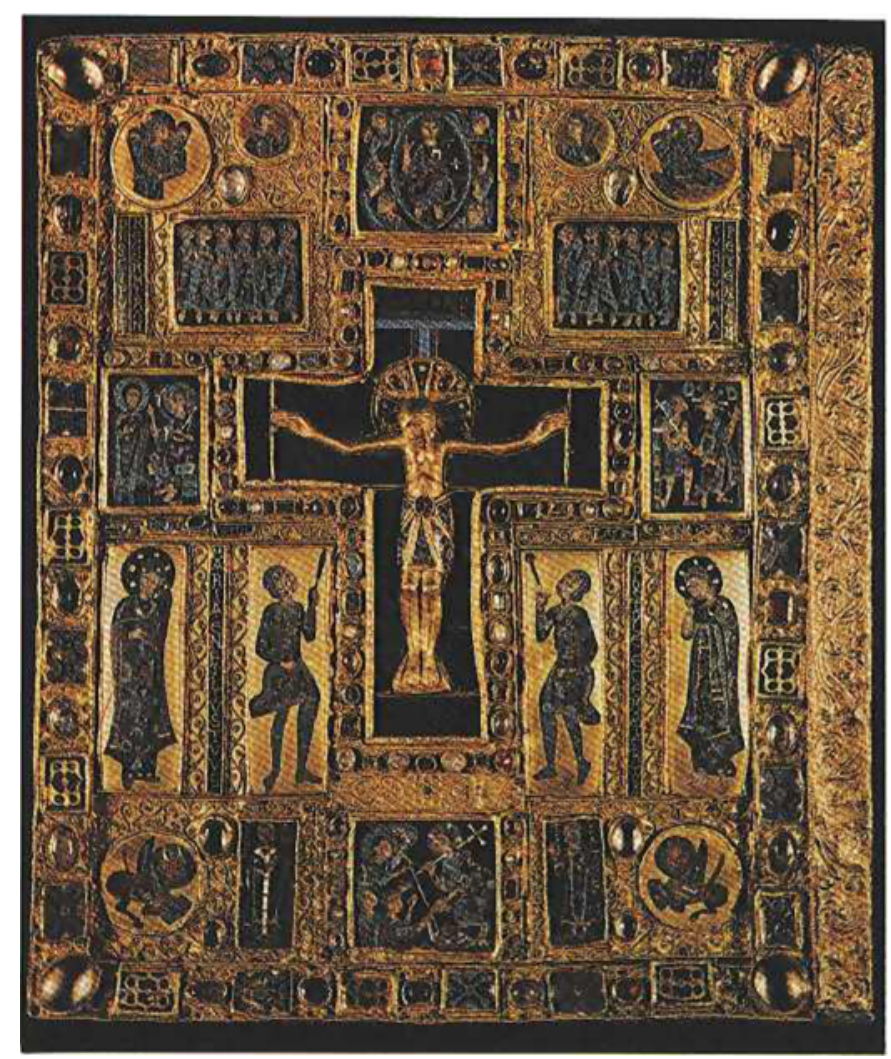

'Evangelistary of Aribert', an 11th century copy of the Four Gospels contained in gold and silver covers adorned with pearls, precious stones and enamels. This is one of the finest examples that survive of early Romanesque overlay. It was once the property of Aribett, Archbishop of Milan, and is now kept in the Cathedral Treasury of that city 


\section{The Tooling and Gilding of Leather}

The custom of tooling leather for covering the wooden boards began only in the 14th century, and continued at least until the end of the Middle Ages. Metal punches and similar tools were used for the dry impressing of decorative motifs. At first, the same method was employed as for stamping copper and silver, but later a special technique was developed. Rich fantasy and a variety of subjects enlivened the work, and in the style of the day Romanesque or Gothic - hunting scenes, winged animals and coats of arms were reproduced, picked out with leaves, branches of oak and vine, and other motifs taken from the world of plants.

Meanwhile, the art of preparing leather and gilding it for the decoration of wall hangings and manuscript bindings had been perfected by the Arabs. In this, they had learned much from the Egyptians and the people of Asia, and in the second half of the 15 th century found a favourable response when they introduced their new ways of treating leather bindings to the western world. These techniques, until then unknown in Europe, were designed to bring into relief, and heighten, the ornamentation of bindings by applying lacquers and liquid or dry preparations containing

A 15th Century Roman missal written and illuminated on vellum sheets bound in red velvet for a Cardinal of the ruling House of Este. The clasps and bosses are in silver gilt. The missal now forms part of the collection of the Trivulziana Library, Milan, manuscript 2165

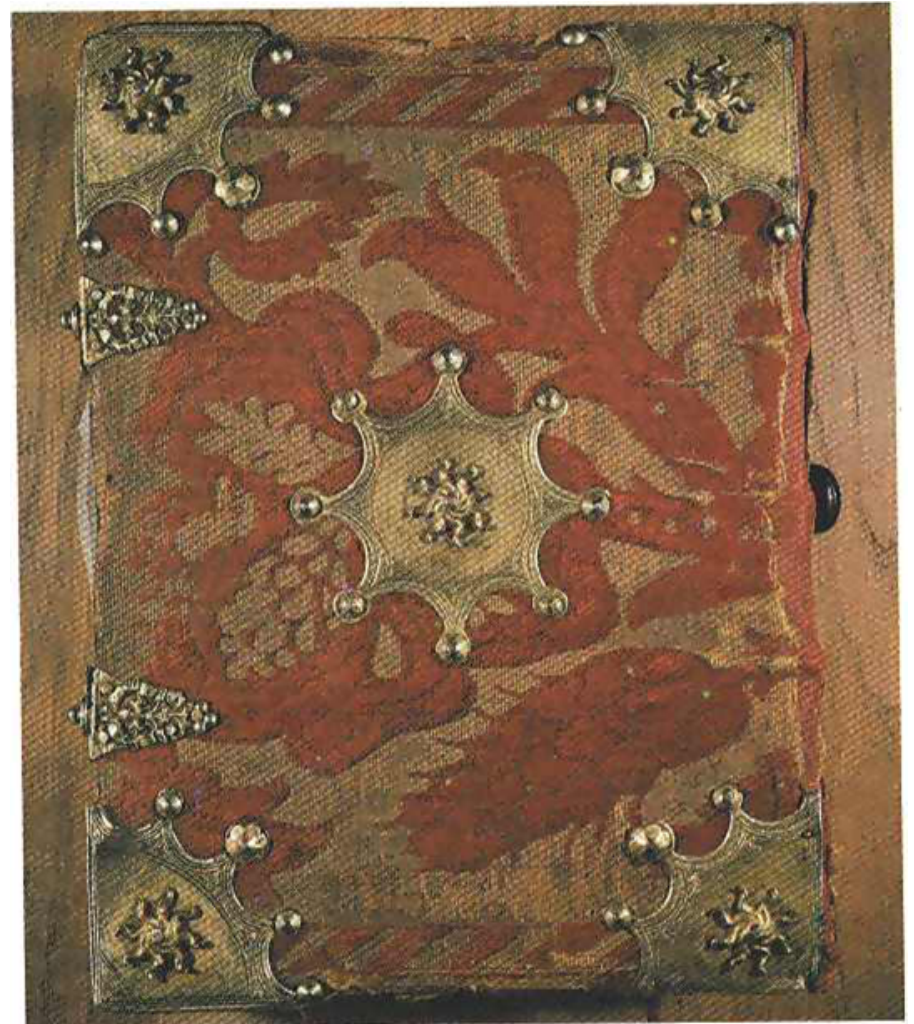

powdered gold to the leather. The art spread rapidly through Italy and Spain, then into France at the beginning of the 1500s.

\section{The Renaissance}

With the revival of the Renaissance spirit in the second half of the 16 th century, refined taste demanded that leather bindings should be adorned in gold with designs of oriental inspiration of the kind already seen on carpets. Hence, the medallion and almond shapes were introduced at the centre of the book cover, and quarter medallions edged with ribbing at the four corners. The principal motif of the Arabs in general, and the Persians in particular, was the Chinese lotus flower linked to small leaves by arabesques and spirals. For Italian and especially Venetian bindings of the Renaissance period, the most widely used motif was the half leaf of the ivy merging into the surrounding braid or other fabric. These motifs were impressed onto the covers in bas-

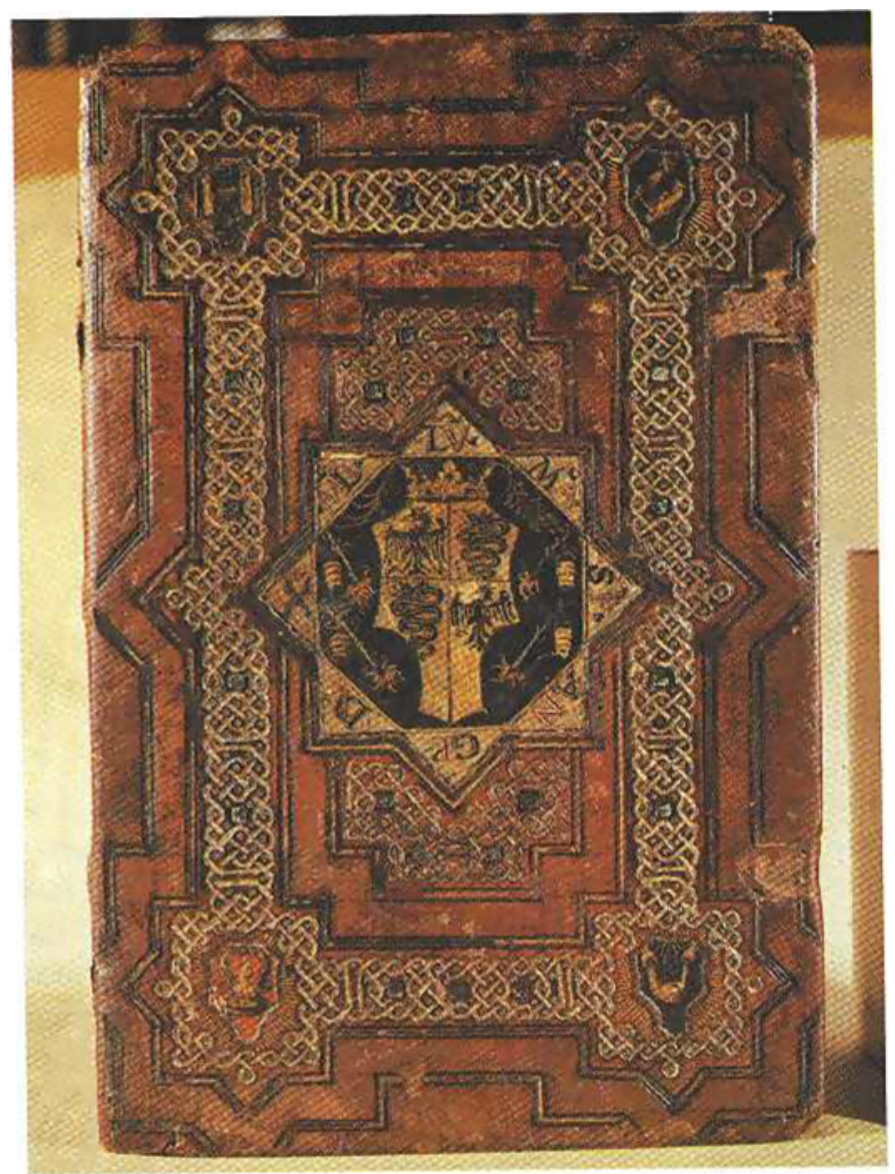

'Book of Grammar' compiled in manuscript form on vellum and bound in leather with decorative gilding for Massimiliano Sforza, son of Ludovico il Moro. The central panel displays the coat of arms of the Sforza family. Late 15th century wotk now entrusted to the Trivulziana Libtary, Milan, manuscript 2167 
relief against a background gilded with lacquers containing powdered gold, by applying strong pressure to dies cut for leatherwork. Alternatively, they would be painted onto the gilded background with coloured lacquers so as to enhance further the final enamel and goldwork. With eastern bindings, the inner face of the cover was often adorned with a perforated design which was enhanced when superimposed on a gold, silver, green or blue base.

\section{The Technique}

As is still the custom, decorative designs were pressed hot onto the leather, and from the very start this called for the use of a variety of implements: a special pad, bronze pressworking tools, pallets, rollers, letter punches and a heater for the tools. Most essential was the mordant for giving luminosity to the leather. For the gold to stick to leather, it was necessary to apply a preparation

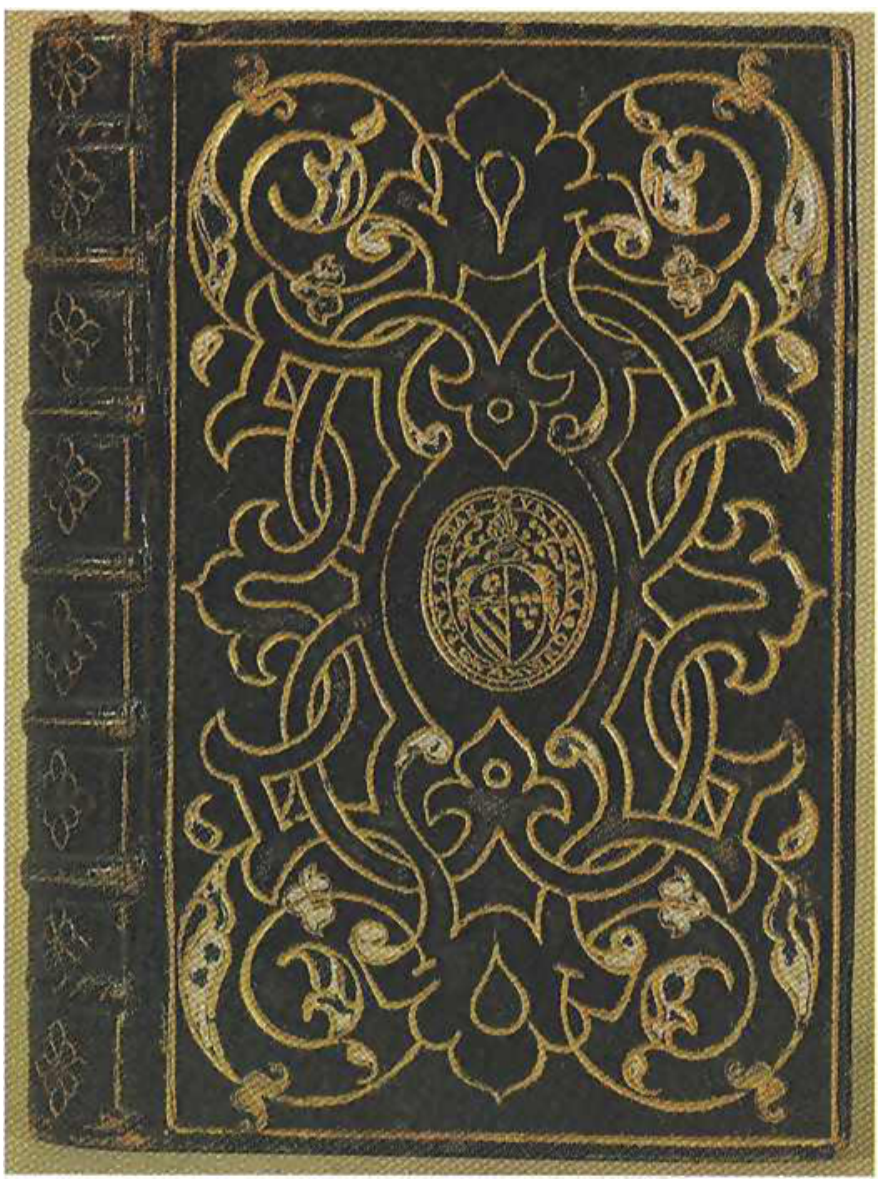

'Stratagemmi di Polieno', a book on the art of warfare published in Venice in 1552. The binding was probably made in Ferrara on the instructions of Tommaso Maioli, a well-known book collector whose role in stimulating the craft is mentioned in this article, and is held in the Trivulziana Library, Milan, inventory number Triv. L3655 of a type still used, since no substitute has been found for it in spite of many attempts to do so. The formula was an extremely simple one: the yolk was removed from one or more eggs, no trace of it being left in the albumen to which was added good quality 'white acid' (vinegar), in volume one-quarter to one-half the amount of egg white, according to the strength required. This was whisked to a froth with a wooden beater, then left to stand for a quarter of an hour before pouring the liquid content, clear of froth and dregs, into another vessel. With a soft brush, the mordant was uniformly spread over the entire book cover, the operation being repeated at least three times after drying. As soon as the final coating was nearly dry, the work of decoration started. Instead of a liquid mordant based on albumen, dehydrated white of egg and white or yellow bleaching powder, (poudre de page), have been used in more recent times for treating silk and velvet, but not always with good results.

\section{Hot Gilding with Leaf}

As mentioned earlier, Easterners, and especially the Persians, were the true pioneers of the art of decorating leather book bindings with gold. Their methods were to be adopted, and im-

'The Venetian Statutes of 1578', bound in red morocco leather with gilded compartments showing, back and front, the lion of St Mark and the Da Ponte coat of arms. A late 16th century work in the 'doge' style referred to in this article, and presently kept in the Trivulziana Library, Milan, manuscript 1331

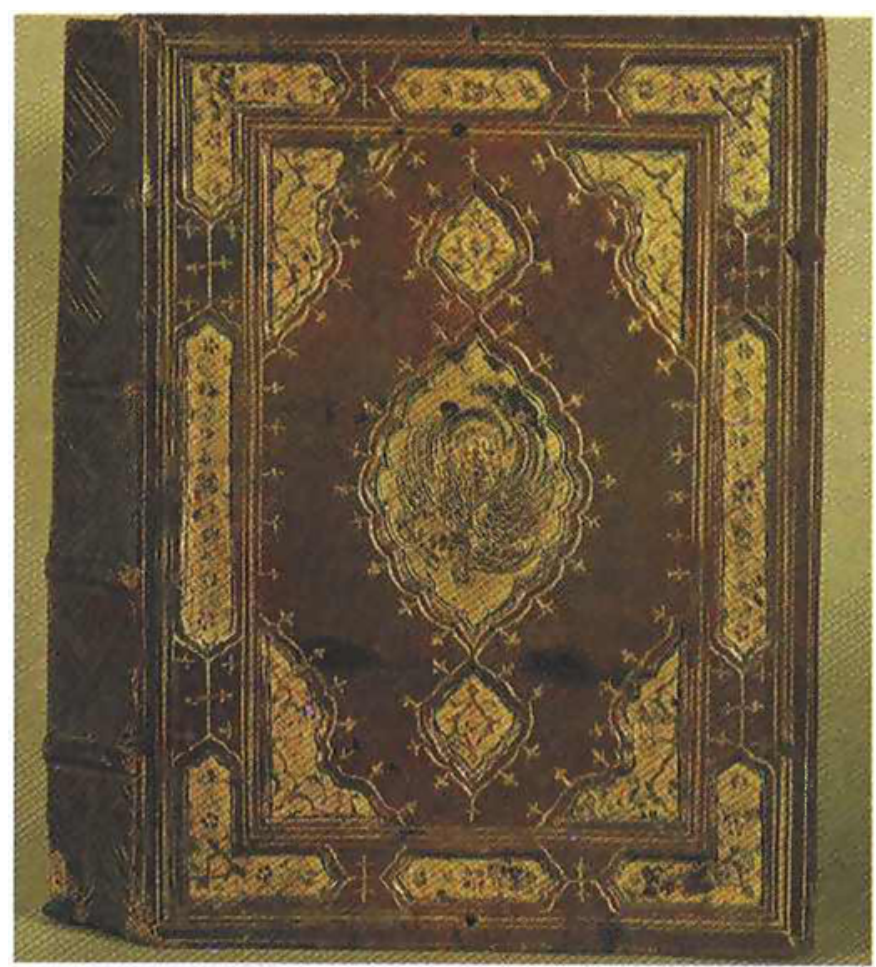




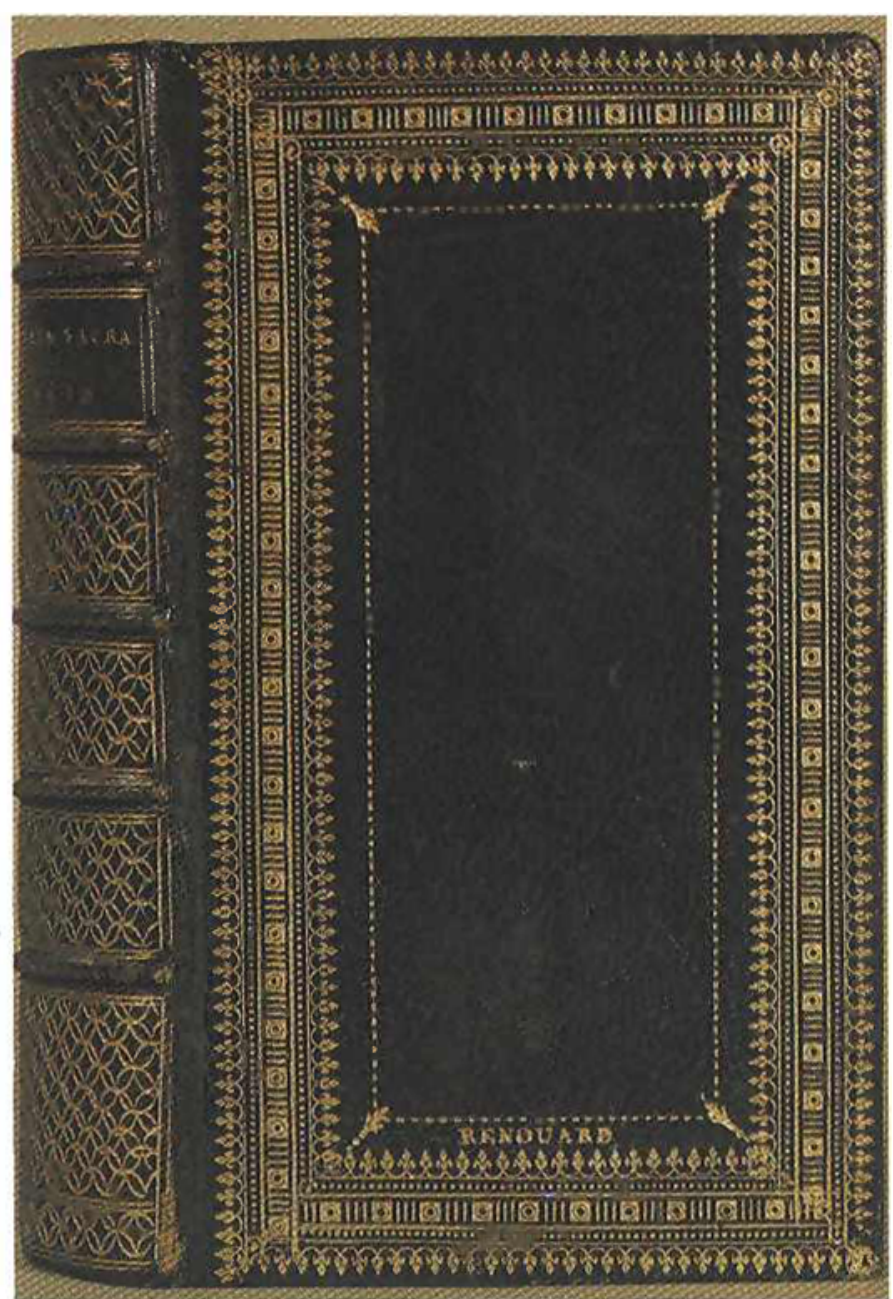

The Holy Bible printed in Cologne in 1630 and bound by the Derome family for the French bibliophile Renouard. Inside, the covers are lined with orange silk adorned with gold lacework in dentelle style. The Bible is held at the Trivulziana Library, Milan, inventory number Triv. L1649

proved upon, in the second half of the 15th century by western binders, influenced, albeit, by Arab artisans working alongside them, particularly in Venice which was then on its way to winning a leading position in European book production. More than other cities of the peninsula, Venice and Naples had learned the oriental methods of treating leather in the course of their overseas trade relations. In fact, in both places it had long been the practice to use liquid gold preparations for the embellishment of book covers and to apply these with a light brush or pen. However, the result was somewhat irregular compared with the effects that were soon to be obtained by using metal tools. Then, in about 1470 , the new technique of hot gilding with leaf emerged. Developed by Italian artisans who had learned it from immigrants from Syria and Egypt, the procedure was to apply the gold firmly with a heated die stamp after treating the leather with a mordant. New impetus was thus given to the production of finely decorated bindings and Italy was quick to make the most of the artistic opportunities that this field offered.

This was the period in which the invention of printing was spreading and, in its wake, book binding was entering a phase of radical reform. The aim was to reduce the mass and format of bindings by substituting pressed paper or cardboard for the wooden under-covers. For ornamentation purposes, appliances that could be operated more rapidly than punches and stamps were coming in: for instance, large plates and metal cylinders for impressing or striking off patterns when sizeable quantities were required. It is said that the pioneers of gilding with leaves and flowers by this method were the artisans at the Aragonese court in Naples. In Florence and Milan, where craftsmen were nothing if not assiduous, bindings began to appear with small gold dots and circles in the interstices of the pattern. At first, these were done in the manner of the oriental craftsmen, using dry powdered gold, which gave a rather dull look; later, hot-pressed gold leaf was used

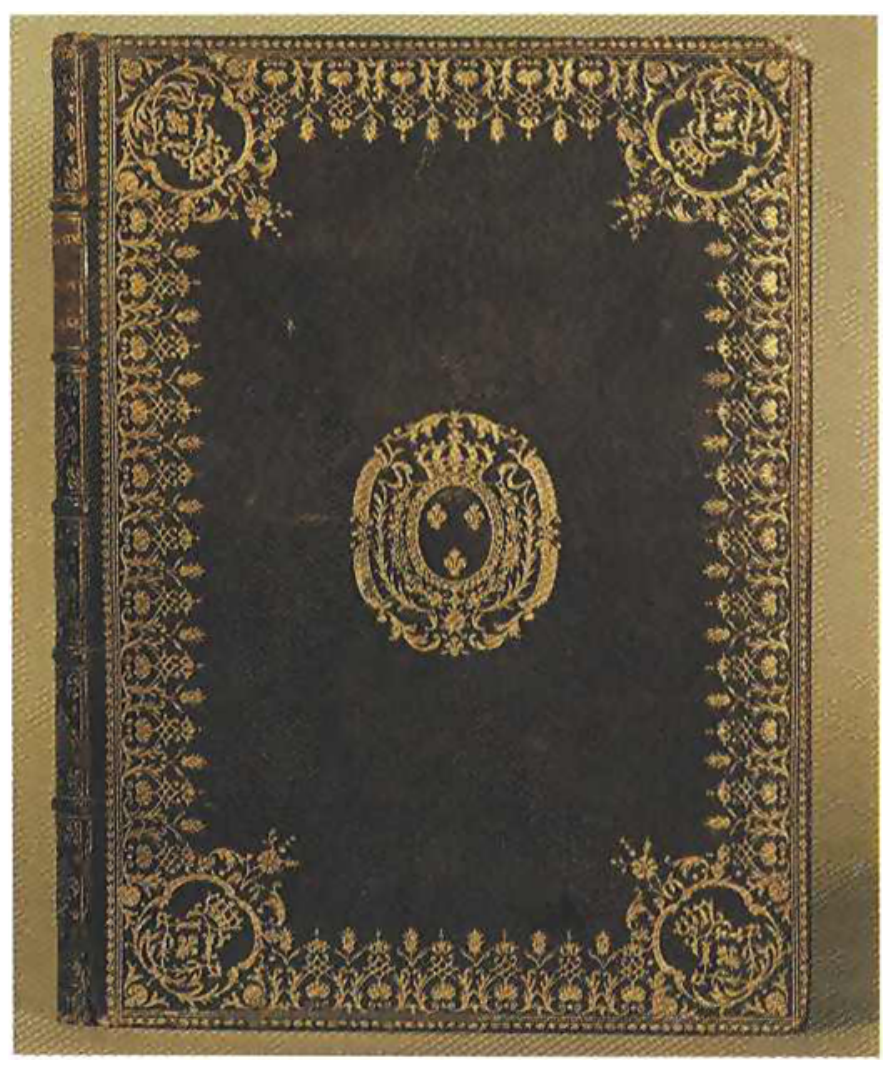

'Theatre de la Guerre en Italie, by Dheulland et Julien of Paris, 1748. This green morocco binding with an elegantly gilded dentelle pattern was made in the Padeloup workshops in Paris in 1748. The royal crest repeated at the corners and in the centre is the coat of arms of Louis XV. The binding is now part of the collection of the Trivulziana Library, Milan, inventoty number Triv. C 28 
with more brilliant effects.

\section{Venice}

It was Venice which established pre-eminence in the art of producing bindings hot-pressed with gold in a style revealing the combined effects of the Renaissance and the East in the choice of motifs, and in the splendour of the gilding and the colouring. Since that city became one of the most important centres of printing, and since it was soon the custom for printing houses to do their own binding and to maintain well equipped workshops and skilled craftsmen for that purpose, the influence and the fame of Venetian book binders spread rapidly.

By the end of the 15th century the bindings that were most admired and progressive were those that came from the house of Aldo Manuzio. The volumes that he produced brought the techniques of his day to perfection, while ornamental motifs which he himself created were designed to please Italian Renaissance taste. They were tooled with straight and curving lines interspersed with flowers and leaves hot-pressed with gold leaf, one at a time by hand. Typically Venetian in style, the tangled leaves formed charming friezes linked by scrolls and volutes - sometimes tenuous and restrained, sometimes superabundant in their gilding - to the title words of the book.

During this same period a taste for classical adornment persisted, and bindings with cameo inserts were produced, especially in Milan, Mantua and Venice. The leatherwork was engraved to portray imperial coins, medallions of mythological scenes, perhaps a portrait of the author, all illuminated in gold. Libraries rich in such books were built up by the Aragonesi, Medici, Malatesta, Visconti and Sforza families at their Renaissance courts. Their shelves, and those of the private collections of keen book lovers like Giovanni Grolier and Tommaso Maioli, were arranged with beautifully miniated codices and the first exemplars of works from famous early printers: volumes bound in leather attistically adorned with gold, or in precious fabrics embossed with gilded studs and engraved clasps.

\section{The Pre-Eminence of Italy}

In the 16th century, books were published and sold in increasing numbers and the work of binding them flourished in all the main printing centres of Italy. The preciosity of the styles now adopted was reflected in covers adorned in gold with decorative geometrical patterns consisting of double parallel lines straight, curved or lozenge-shaped - enriched with spirals and arabesques. Then, in the late Renaissance, when the custom started of placing books upright on the shelves, greater attention was also given to the spines of the volumes. As well as displaying title and author, the spine was now decorated with geometrical and floral patterns in gold of the finest quality. The principal motif applied to many of these bindings, whether they were made in Italy or by Italian artisans in other countries, notably France, was composed of a diamond and a rectangular figure interwoven to form an infinity of patterns when embellished with convoluted tendrils and arabesques.

In Northern Italy, above all in Milan, the influence of Leonardo da Vinci extended in no small degrec even to this minor art form. Thus, to attain a more exquisite effect, new die stamps styled with leaves and flowers were constantly being designed. They were called aldi after Aldo Manuzio: aldi pieni, vuoti and al tratteggio (solid, blank and broken line). Combined with spirals and volutes they were applied to the empty spaces in geometrical patterns of lines and friezes with striking and stylistically perfect results. Up to the end of the 16th century, bindings with this kind of goldwork were found all over Europe, most of them from Italian prototypes otiginating in Venice, Milan, Mantua, Turin, Genoa, Ferrara, Bologna, Florence and Rome. Some were quite magnificent, classical but original in composition, endless in variety and harmonious in general appearance. The décors included structural compositions, scrolls and plaques in goldwork, intervening sections with gold dots, lively colour effects obtained with leather applique work and lacquer paint. All this gave resplendence to 16 th century bindings. It was during this period that decorative work was first used on inside covers and the edges finely gilded.

At this time, many volumes were specially prepared for the two great bibliophiles whom we have already mentioned, Tommaso Maioli and Jean Grolier, who were themselves arbiters of the craft and gave their orders to the best Italian workshops. Of Italian origin, they were on friendly terms with the humanists and book lovers of the day and were well known to Aldo Manuzio. Both Maioli and Grolier insisted that their designs should not be repeated on bindings prepared for other collectors. While the former preferred gilded work of lively movement, the latter favoured a style that was strictly geometrical in its combination of interlaced circles, semi-circles, lozenges and borders, all of which were much in vogue at the time. Grolier, who returned from Italy to his native city of Lyons in 1534 , set up a bindery in that town and employed Italian artisans. It is to his credit that he introduced the Italian Renaissance type of binding into France, where such work was still 'clumsy and heavy' in appearance.

In the mid-16th century, bindings were being produced in Italy which were fine in technique, as well as in the quality of a new decorative style expressed in ribbon-shaped borders that gave added splendour to the gilding. Even when mosaic effects were introduced by applying morocco leather inlays in various colours, goldwork was still abundantly used for the lines that delimited and at the same time united the parts of the décor.

\section{The Rest of Europe}

In other European countries, notably France, England and Germany, bindings showing Italian influence began to appear at the end of the 1400s and in the early 1500 s, but they lacked precision in the technique and attistry of their gilding. Then, towards 
the end of the 16th century, Italy too adopted larger gilding tools which were quicker and easier to use, but did not give such scrupulously detailed results as earlier techniques. The new die stamps portrayed vases, caryatids, masks, chimeras, dolphins and winged cherubs among others. Elsewhere, especially in Venice where classical Renaissance motifs were dwindling in number because of changes in fashion, binders took inspiration from the East and designed heavy borders in bas-relief that were deeply alveolated along the edges of the panel and at its four corners. These were called 'doge' or 'Venetian style' bindings.

With the advent of the 17th century, tastes in the decorative gilding of book bindings with hot stamps changed with the development of this craft: new patterns displaying twisting parallel lines impressed in triplicate, with scrolls and cylinders in the corners, were introduced. Meanwhile, in Italy this type of craftsmanship fell into decline, partly due to politico-social changes, so that the country soon lost pre-eminence in this field. In Rome, Turin and Milan, striking effects continued to be produced on vellum bindings with gold that contrasted well with the lack-lustre of a matt background. Meanwhile, in France, where gilding was second only to Italy in the extent of its development, new die stamps were designed for the spirals and volutes, and the tendrils of oak and laurel, with which the spaces in geometrical patterns were filled. This trend freed France from Italian influence and left her craftsmen to follow an independent and wholly original course which for a long time gave them the lead, patronised as they were by the Court and the nobility, and inspired by the skills of such binders as Le Gascon, Badier, Eve, Ruette and Boyet.

During the reign of Louis XIII in the first half of the 17 th century, the master binder Le Gascon launched a novel and elegant style of gilding known as filigrane or pointille, which spread to other countries, Italy included. However, its ostentatious appearance brought about a sharp reaction and the adoption, at least in France, of the Janséniste binding in deference to the austere leanings of that sect. At first, no more than a simple fillet of gilding was admitted, but to this was soon added a richly ornate lacework border, precursor of the French dentelle style which was later to focus inwards on the coat of arms or initial letters that occupied the centre of the cover. As the century progressed, Italy turned towards ornamental styles featuring fan-shaped motifs, plain and simple in Milan and Turin, more lavish and precious in Rome and Florence. Gilded at the four corners with a lacework pattern resembling a fan, the cover was left blank at the centre in the form of a circle.

The rococo style of the 18th century pointed the way to yet another fashion in the adornment of bindings, one which was quickly developed and propagated by the Padeloup and Derome families, and which was unmatched for the rest of the century. For five generations, from 1642 to 1795 , the Padeloups used warm shades of orange, rose, blue and pea green for their morocco leather bindings. These, they gilded with dots and geometrical shapes that were repeated to suggest parquetry and decorated richly with mosaic patterns and wide borders in lively colours displaying rococo influence. The Deromes specialized in bindings in keeping with the Louis XV style, embellishing them with gilded designs derived from Venetian lace and embroidery. Highly skilled in the use of small stamps, they contrived original groupings of tendrils, fronds and flowers, in particular of the carnation, rose and pomegranate, without omitting the rococo emblem of the shell from the cover corners, nor, when appropriate, the patron's crest from the centre of the panel.

Bindings were also produced in the French manner in Italy, but here the 18th century ushered in an entirely original style dominated by gilded bands which wound around latticed pads at the corners of the central panel, flowing inward often to usurp the place normally reserved for a coat of arms. The leather was of natural hue, though sometimes tinted with an undertone or streak of colour.

Meanwhile, England was held in spell by that most famous of bibliophiles, Robert Harley, Earl of Oxford, founder of the Harleian Collection at the British Museum. He prepared his own designs for the bindings of books that went into his library. And their motifs, taken from plant life, gave English bindings a distinctive style and character which endures to this day.

\section{Later Developments}

In Italy, Harley's most recent counterpart was Baron Weil Weiss (1863-1939) who devoted his life to collecting fine editions which he had bound by the best artist binders then working in Paris and Turin. Of these, Giovanni Pacchiotti is the mostcelebrated, at least in Italy, if only because he bound and decorated 475 works of the 7000 items which comprise the Weiss Collection of Art Bindings in the Trivulziana Museum, Milan.

An examination of their styles shows how greatly the art of adorning leather bindings has changed in the last hundred years. The search for original motifs led to the introduction of a wide variety of floral, figurative, even geometrical embellishments; the tendency became more thematic, more fantastic, depending on the content of the book, sacred, profane, literary or scientific. However, this is a subject that lies outside the range of this article, involving, as it does, the place of art and design in modern book binding.

Suffice to say that traditional motifs have by no means been abandoned and that much of the best work done today reflects the classic designs that have been discussed here. Furthermore, since gold, when applied by artists of experience and taste, has never failed to enhance fine leatherwork, we may be sure that book binders will continue to use it as long as beautiful presentation volumes are appreciated.

\section{Acknowledgement}

This text was translated from the Italian by Michael P. A. Langley. 